The $B D J$ News section accepts items that include general news, latest research and diary events that interest our

readers. Press releases or articles may be edited, and should include a colour photograph if possible. Please direct your correspondence to the News Editor,

Arveen Bajaj at the BDJ, The Macmillan

Building, 4 Crinan Street, London N1 9XW

or by email to bdj@bda.org

\section{Stem-cells that regenerate}

A researcher from the University of Southern California (USC) USA has identified stem cells in tendons that regenerate tissue.

Dr Songtao Shi from USC's Center for Craniofacial Molecular Biology, a division within the USC School of Dentistry, has published numerous studies on the role of stem cells in regeneration and was part of an international research team that successfully generated tooth root and supporting periodontal ligaments to restore tooth function in the animal model.

Dr Shi has identified unique cells within the adult tendon that have stem-cell characteristics including the ability to proliferate and selfrenew. The research team was able to isolate these cells and regenerate tendon like tissue in the animal model.

By looking at tendons at the molecular level, the research team identified a unique cell population termed tendon stem/progenitor cells (TSPCs) in both mice and adult humans that when guided by a certain molecular environment, form into tendon cells. Their findings hold promise for the treatment of tendon injuries caused by overuse and trauma.

He says, 'Clinically, tendon injury is a difficult one to treat, not only for athletes but for patients who suffer from tendinopathy such as tendon rupture or ectopic ossification. This research demonstrates that we can use stem cells to repair tendons. We now know how to collect them from tissue and how to control their formation into tendon cells.'

The paper appears in Nature Medicine and is online at www.nature.com/nm.

\title{
Association welcomes new President
}

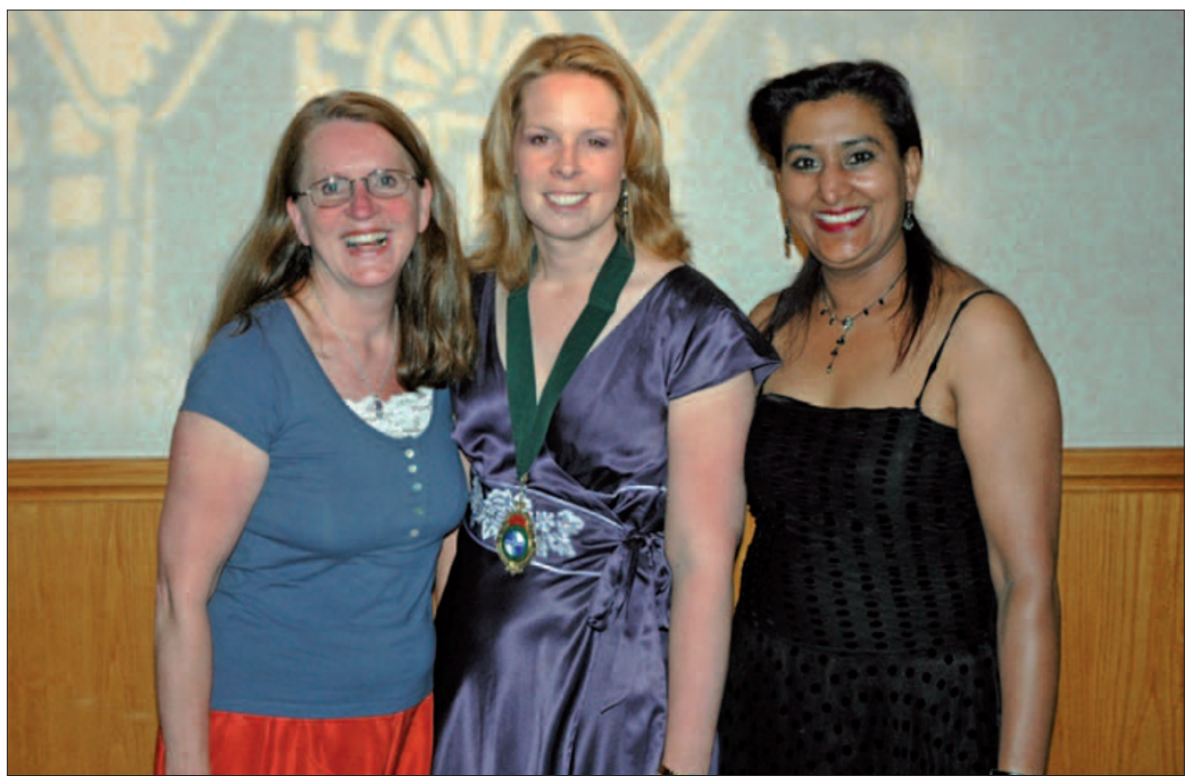

The British Association of Dental Therapists (BADT) welcomed its incoming President at its Annual Scientific Meeting earlier this year. Leigh Ann Randell, who is a dually-qualified dental therapist/ hygienist has been involved in the BADT council for several years, most recently as the Chairman.

She hopes to continue to represent the BADT across the dental profession and to represent the current needs of dental therapists/hygienists within this arena. Ms Randell took over from Hazel Fraser who completed her term of office as President of the Association after four years. Pictured from left to right, Hazel Fraser, outgoing President, Leigh Ann Randell, President and Baldeesh Chana, Chairman.

\section{Charity web presentation to be held}

A live interactive web presentation about the work of dental charity Bridge2Aid is to take place on 24 0ctober 2007, with $£ 20$ of the $£ 45$ fee going to Bridge2Aid.

Dr Ian Wilson and Mr Mark Topley from the charity will be hosting the webinar which carries two hours verifiable CPD.

Part of the charity's role is to provide volunteering opportunities to UK dentists and DCPs to help train local Rural Clinical Officers to provide safe, basic care. These are usually two week placements so this event will be particularly valuable for those who have considered short-term voluntary service overseas.

Entitled 'Dental NGOs and Primary Oral Health Care in Developing Nations', topics include access to primary oral health services in developing nations, the 'cost' of culture and community development amongst the poor. 


\section{Students questioned on work-life balance}

A survey of senior dental students published in the $B D J$ has found that $18 \%$ of them plan to work exclusively within the private sector while only $3 \%$ intend to work wholly within the NHS.

Final-year dental students at the Universities of Dundee and Manchester were asked about their future career plans, with particular emphasis on work-life balance issues, their attitudes towards the NHS, and retirement plans.

The study, led by researchers at the University of Dundee raises questions over future workforce planning for dentistry within the NHS. The study also found that around 60\% of students foresaw themselves retiring from the profession or reducing their working commitment before they were 60. More than half the students also said they would plan to take time out of dentistry once they had started families.

The survey was carried out by principal investigator Dr Fiona Stewart and Dr John Drummond, both at the University of Dundee, Dr Lloyd Carson at the University of Abertay Dundee, and Dr Elizabeth Theaker at the University of Manchester.

Lead author Dr Stewart, whose principal research interest is the work pattern of dental professionals, commented, 'The results of this study suggest that future generations of dentists will have a pattern of professional life that may have the effect of reducing their clinical commitment, both in terms of working time and participation in patient care within the NHS.'

She added that the findings indicated that the plans senior dental students had for their future careers may reduce the 'supply side' of the workforce equation, particularly with respect to their intentions regarding NHS work, childcare arrangements and retirement plans.

'If these career intentions are followed through it could impact significantly on the future clinical commitment available to the NHS, and in our view these intentions should be taken into account for future dental workforce planning,' she said.

A similar study published two years ago by the same authors questioned younger entrants to dental school and found similar numbers (3\%) intending to dedicate their careers wholly to the NHS. The biggest difference in the results this time lay in the proportion of students intending to work wholly in the private sector.

'When we previously spoke to younger students the number looking to work exclusively in private practice was $7.5 \%$. This time we have spoken to more senior students and that figure has jumped to $18 \%$. That may reflect changes in attitude as students progress through their training,' said Dr Stewart.

The vast majority, 79\%, expressed intent to share their workload between the NHS and the private sector. The results of the survey were published in the British Dental Journal 2007; 203: 257-263.

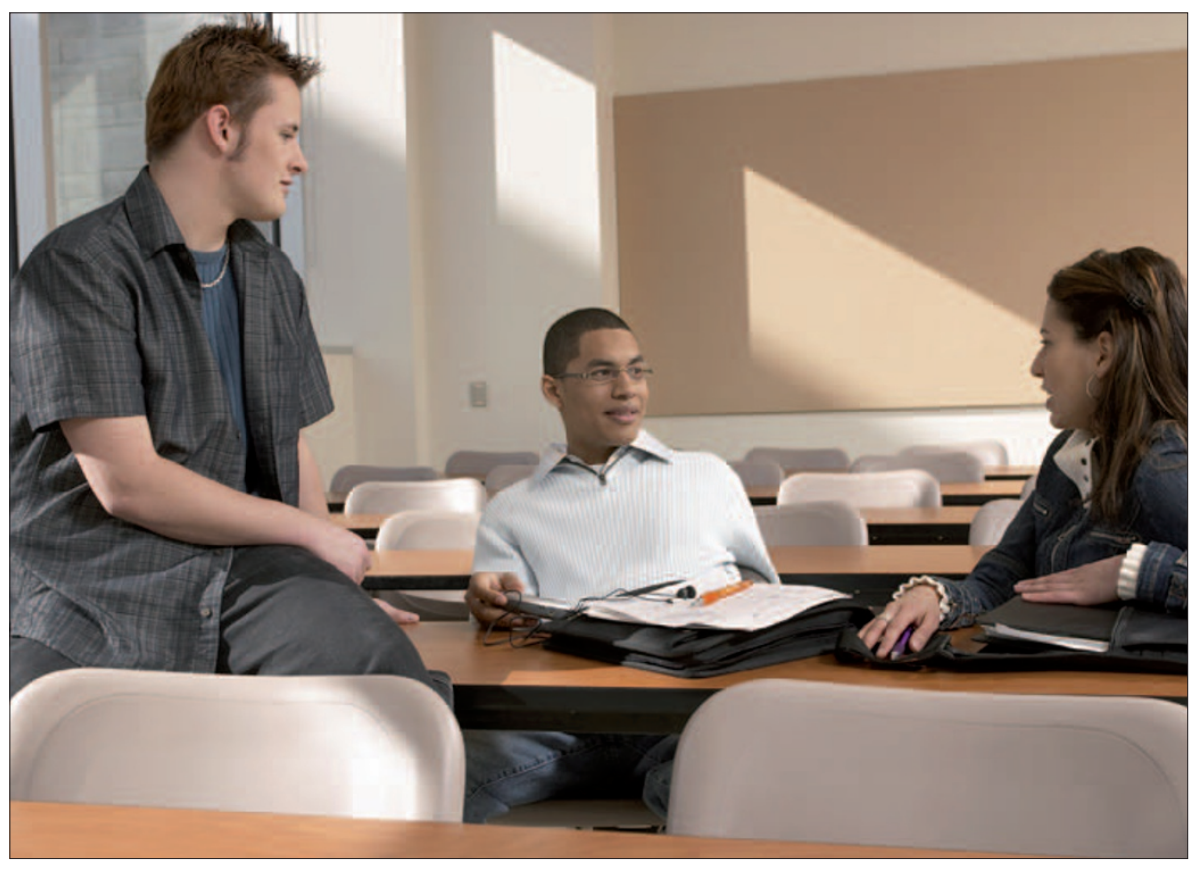

\section{Newly launched award recognises innovation}

A new award has been launched which recognises contributions to and support of global oral health and education initiatives. The American Dental Education Association (ADEA) Gies Foundation has announced the launch of the William J. Gies Awards for Vision, Innovation, and Achievement. The award will be presented annually in conjunction with the ADEA Annual Session and Exhibition.

William J. Gies, a pioneer in dental education, was a Columbia University biochemistry professor interested in dental education, science, and clinical applications. In 1926, as part of a series of studies on US professional education Dr Gies published a landmark report that established the importance of dentistry as a healing science and an essential component of higher education in the health professions. Dental Education in the United States and Canada remains a relevant survey of dental education and critical issues within the field.

The ADEA Gies Foundation will honour deserving people and entities that carry forward Gies' legacy of vision, innovation, and achievement. The honorees will be selected by a panel of judges consisting of the ADEA Gies Board of Trustees.

For more information visit www. adeagiesfoundation.org. 


\section{Vaccine may decrease chances of oral cancer}

Human Papilloma Virus (HPV) vaccines may decrease chances of oral cancer according to a recently published study. HPV is linked to oropharyngeal cancer and may be linked to oral cancers as well, and vaccines that have been developed to treat it might decrease the risk of these cancers, according to a study in General Dentistry (2007; 55: 252-254), the journal of the Academy of General Dentistry (AGD).

Dr James J. Closmann, lead author of the study, found that oral and oropharyngeal squamous cell carcinoma (OOSCC) have been linked to high-risk HPV strains, the same strains that cause cervical cancer. He adds that recently a vaccine was developed to treat patients with HPV against cervical cancer and this could have an effect on women's oral health.

'More than 100 strains of HPV have been identified and have been shown to cause other benign and malignant disorders, which now include those in the mouth. Nearly 30,000 new cases of oral and oropharyngeal cancer are reported each year. It is possible that oral and oropharyngeal cancers could be reduced if vaccination were more widespread; however, additional research is needed,' says Dr Closmann.

Further research could result in a comprehensive test for dentists at patients' semi-annual visits. However, a dentist can perform a head and neck exam to detect early signs, despite the lack of a specific test. A possible connection between HPV and oral cancers, and the stronger link to oropharyngeal cancers, is even more of an indicator that patients should visit the dentist twice a year to identify irregularities early, Dr Closmann added.

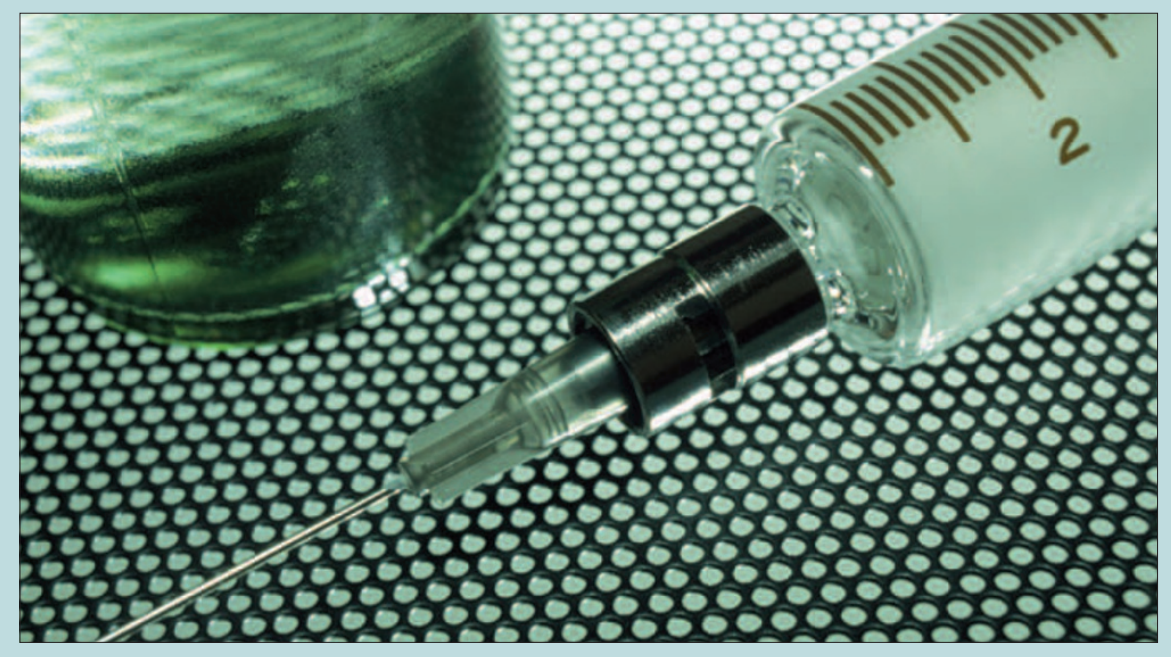

\section{$B D J$ makes an impact say latest results}

The British Dental Journal's (BDJ) 2006 impact factor has increased by 29\%. Announced by Thomson ISI, a journal's impact factor is a measure of how highly cited its papers are and is a reflection of the number of citations in a given year (in this case 2006) to papers published in the journal in the previous two years (ie 2005 and 2004). The BDJ's impact factor is 0.848 , up from 0.658 last year.

The journal also has its finger on the pulse in terms of up-to-date content, as the $B D J$ 's immediacy index also increased significantly in 2006 - up to
1.165 from 0.350 in 2005, an increase of $233 \%$. The immediacy index is a measure of how current the content of a journal is, reflecting the number of citations in a given year (2006) to papers published in the journal in the same year.

Kim Black-Totham, BDJ Publisher commented, 'We are very pleased to see this increase in both impact factor and immediacy index. Our aim is always to publish papers that are relevant and current to dentistry. It is gratifying to know that we are achieving our goal and great to see that reflected in this year's figures.' 


\section{DIARY}

September

4th Annual Meeting of the European Society of Esthetic Dentistry Date: 21-23 September 2007

Venue: Vienna, Austria

Email: iris.bobal@media.co.at www.escdonline.eu

American Dental Association Date: 27-30 September 2007 Venue: The Moscone Center, San Francisco, USA www.ada.org

\section{October}

British Society for the Study of Prosthetic Dentistry Symposium Date: 5 October 2007

Venue: Bristol

Email:R.Jagger@bristol.ac.uk

British Society of Oral Implantology Date: 6 October 2007

Venue: The University of Glamorgan Email:support@BSOI.org www.BSOl.org

Oral Cancer: Challenges and Solutions Date: 6 October 2007

Venue: UCL Eastman Dental Institute, London

www.eastman.ucl.ac.uk

\section{BDTA Dental Showcase}

Date: 18-20 October 2007

Venue: NEC Birmingham

Tel: 01494789959

www.dentalshowcase.com

North of Scotland BDA Conference and Ceilidh

Date: 20 October 2007

Venue: Apex Hotel and Spa, Dundee Email: bdascotland@hotmail.com

Tel: +44 (0)1382635964

Annual meeting of the Society of Craniofacial Genetics \&t American Society of Human Genetics

Date: 23 October 2007

Venue: Convention Center, San Diego, California, USA

www.craniofacialgenetics.org

FDI Annual World Dental Congress Date: 24-27 October 2007

Venue: Dubai, UAE

Email:congress@fdiworldental.org www.fdiworldental.org

\section{Visit for dental school}

The University of Sheffield's School of Clinical Dentistry was the focus of a visit from the President of the General Dental Council, Hew Mathewson, earlier this month. The school is renowned for its clinical placement outreach programme, which provides students with several weeks of training in local 'high street' NHS funded dental practices.

Professor Trevor Walsh, Dean of the School of Clinical Dentistry at the University, said, 'Our clinical placement outreach programme is an award-winning, quality project that brings major benefits to both our student dentists and the local population.'

As part of the visit, Mr Mathewson toured the Mount Dental Practice in Hemsworth, Pontefract, one of the University's most recent partnerships. Amita Shahi, owner of the practice, has built three new surgeries specifically so she can offer placements to university students.

The University's clinical placement outreach programme provides students with work placements in local general dental practices and NHS dental clinics, where they provide a full range of treatment to patients under the supervision of local dentists. Placements, currently six weeks full-time, are being increased to six months (experiencing three different services) starting 2007/2008.

Hew Mathewson added, 'As the UK dental regulator, one of the General Dental Council's most important roles is setting educational standards. We encourage dental course providers to be innovative with their programmes. Outreach is an exciting and demanding development for dental schools and the University of Sheffield has been at the forefront of this.'

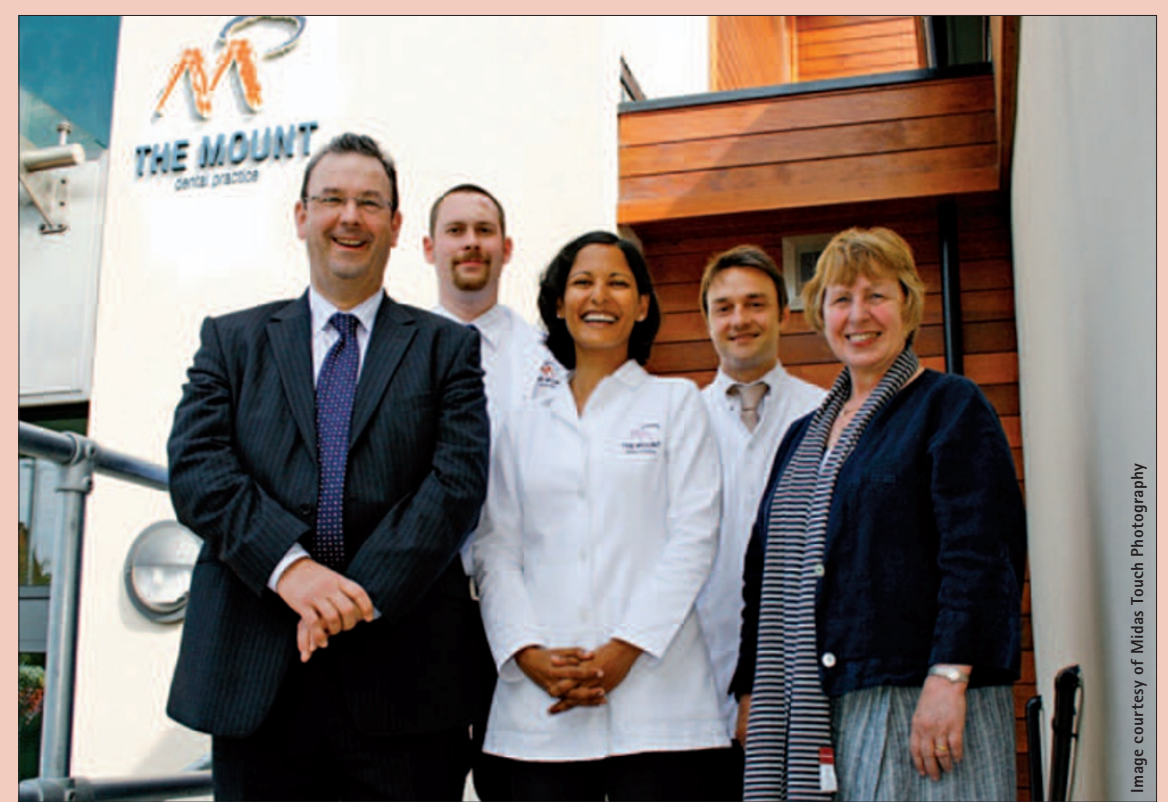

Hew Mathewson (GDC), with Richard Main, Amita Shahi, Scott Senior and Christine Abbott

\section{IT security misconceptions revealed}

Europe's healthcare sector small and medium sized businesses (SMBs) believe they are 'not valuable enough' for cyber criminals and are leaving themselves open to IT security attacks due to a lack of time and resources, according to a new survey.

Around 22\% of SMBs in this sector have less than one hour a week to spend on proactive IT security management despite the same percentage acknowledging that an attack could put them out of business. The research from McAfee into SMBs' attitudes and beliefs towards IT revealed that $44 \%$ think cyber crime is an issue for larger organisations, 22\% of healthcare sector SMBs believe that because they are not well-known they are not on the radar of cyber criminals and 56\% do not think they can make a cyber criminal any money.

Countries surveyed were the UK, France, Italy, Germany, the Netherlands and Spain. 